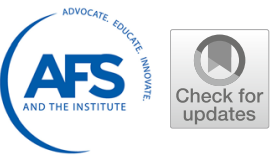

\title{
ANALYSIS OF THE MECHANICAL PROPERTIES OF SECONDARY AIZnMg(Cu) DIE-CAST ALLOYS
}

\author{
Mathias Silmbroth 1 and Salar Bozorgi \\ School of Engineering, University of Applied Sciences Upper Austria, Stelzhamerstraße 23, 4600 Wels, Austria \\ Salar Bozorgi \\ LKR Light Metals Technologies Ranshofen, Austrian Institute of Technology, Lamprechtshausenerstraße 61, 5282 \\ Ranshofen, Austria
}

Copyright $(\subset) 2020$ The Author(s)

https://doi.org/10.1007/s40962-020-00510-6

\begin{abstract}
In this work, the development of $\mathrm{AlZnMg}(\mathrm{Cu})$ alloys was performed by thermodynamic simulations and experimental tests. With calculations, the solidification processes and phase compositions could be predicted. As secondary casting alloys, the selected compositions of AlZn4Mg3$\mathrm{Cu}(\mathrm{Fe})$ and $\mathrm{AlZn} 5 \mathrm{Mg} 4 \mathrm{Cu}$ have higher contents of alloying elements, such as iron and silicon, and were successfully processed with a cold-chamber die casting machine. In addition, an energy-and time-saving optimization of the material properties was performed by a modified heat treatment (T6*) with a total time of only $12 \mathrm{~h}$. The alloys

were evaluated based on the characterization of their mechanical properties and the analysis of their microstructures. In particular, the elimination of cost-intensive alloying elements and the application of a modified heat treatment method clearly show the potential of $\mathrm{AlZnMg}(\mathrm{Cu})$ die-cast alloys for future industrial use.

Keywords: high-pressure die casting, $\mathrm{AlZnMg}(\mathrm{Cu})$ alloys, microstructure analysis, intermetallic phases, optical microscopy, SEM, EDS

\section{Introduction}

The development of sustainable production methods is prompting resource-saving ways to produce load-bearing lightweight components. In this context, the use of secondary aluminum offers attractive opportunities, as up to $95 \%$ of the energy required for primary production can be saved. ${ }^{1}$ Secondary alloys fulfill the requirements in die casting and enable a cost-efficient production of complex components. Furthermore, $\operatorname{AlZnMg}(\mathrm{Cu})$ wrought alloys reach tensile strengths above $700 \mathrm{MPa}$; hence, these alloys satisfy the mechanical requirements in structural components. ${ }^{2}$ The alloying elements zinc, magnesium, and copper with a proportion of $0.5-2$ wt.\% form complex intermetallic phases that control the material properties and enable high hardenability and high strengths. ${ }^{3,4}$ First, the $\eta-\left(\mathrm{MgZn}_{2}\right)$ phase must be mentioned, which is a hexagonal Laves phase in which extremely dense packings are formed due to favorable atomic radii. ${ }^{5}$ In dependence of the geometrical and chemical conditions, many possible stoichio-

possible, but the phase is usually specified with $\mathrm{MgZn}_{2}{ }^{6}$ In this phase, zinc can be substituted by aluminum and copper, but high copper content has a destabilizing effect. ${ }^{6,7}$ In addition, the cubic $\mathrm{T}-\left(\mathrm{Al}_{2} \mathrm{Mg}_{3} \mathrm{Zn}_{3}\right)$, orthorhombic $\mathrm{S}-\left(\mathrm{Al}_{2} \mathrm{CuMg}\right)$, and, at high zinc levels, cubic $\mathrm{Z}-\left(\mathrm{Mg}_{2} \mathrm{Zn}_{11}\right)$ phase can occur. Both $\eta$ - and T-phases form a quasi-binary eutectic with aluminum. In general, the occurrence of these phases depends on the concentration ratio of $\mathrm{Zn} / \mathrm{Mg}$. At a ratio $\mathrm{Zn} / \mathrm{Mg}>2$, the formation of $\eta-\left(\mathrm{MgZn}_{2}\right)$ predominantly occurs; at $\mathrm{Zn} / \mathrm{Mg} \leq 2, \mathrm{~T}-\left(\mathrm{Al}_{2} \mathrm{Mg}_{3} \mathrm{Zn}_{3}\right)$ dominates. $^{8}$ For a long time, only $\mathrm{MgZn}_{2}$ was investigated for precipitation strengthening. However, in most commercially used $\operatorname{AlZnMg}(\mathrm{Cu})$ alloys, both $\eta$ - and T-phases occur. The $\mathrm{Zn} /$ $\mathrm{Mg}$ ratio and combined $\mathrm{Zn}+\mathrm{Mg}$ content are crucial for the final properties of $\operatorname{AlZnMg}(\mathrm{Cu})$ alloys. With a $\mathrm{Zn}+$ $\mathrm{Mg}$ content of 2-5 wt.\%, little or no hardening effect is present, whereas good castability is given only up to a $\mathrm{Zn}+\mathrm{Mg}$ content of approximately $6 \mathrm{wt} . \%$. Although high $\mathrm{Zn}+\mathrm{Mg}$ contents lead to high strengths, they also increase the susceptibility to stress corrosion cracking. ${ }^{10}$
\end{abstract} metric compositions from $\mathrm{MgZn}_{2}$ to $\mathrm{Mg}(\mathrm{ZnAlCu})_{2}$ are 
Copper affects the precipitation kinetics of the alloys and significantly increases the strength. At a ratio of $\mathrm{Cu} /$ $\mathrm{Mg}<1$ or a copper content $<2.5 \mathrm{wt} . \%$, the element is predominantly dissolved in $\eta$ - and $T$-phases. ${ }^{9}$ In the $\mathrm{Al}+\eta-\left(\mathrm{MgZn}_{2}\right)$ eutectic, $16-18$ wt.\% copper is soluble, which results from the high copper solubility of $\mathrm{MgZn}_{2}$. It promotes the formation of $\eta-\left(\mathrm{Mg}(\mathrm{Zn}, \mathrm{Al}, \mathrm{Cu})_{2}\right)$, since more copper can be dissolved here than in $\mathrm{T}-\left(\mathrm{Al}_{2} \mathrm{Mg}_{3} \mathrm{Zn}_{3}\right)$ (27-28 wt.\% Cu) ${ }^{10}$. However, high copper contents cause the formation of $\mathrm{S}-\left(\mathrm{Al}_{2} \mathrm{CuMg}\right), \theta-\left(\mathrm{Al}_{2} \mathrm{Cu}\right)$, and in combination with iron, of $\mathrm{Al}_{7} \mathrm{Cu}_{2} \mathrm{Fe}$. Particularly for corrosive reasons, the formation of such phases is undesirable. Therefore, the complete solution of copper in $\eta-\left(\mathrm{MgZn}_{2}\right)$ and $\mathrm{T}-\left(\mathrm{Al}_{2} \mathrm{Mg}_{3} \mathrm{Zn}_{3}\right)$ particles is preferred.

In the heat treatment, $\eta$-phases rapidly dissolve in the aluminum matrix. $\mathrm{T}$ - and $\mathrm{S}$-phases show a more difficult solution behavior, which results from their higher formation temperatures. ${ }^{11}$ In general, the precipitation sequence of $\mathrm{AlZnMg}(\mathrm{Cu})$ alloys can be subdivided into: ${ }^{2,12}$

Supersaturated $\alpha_{\mathrm{Al}} \rightarrow$ clusters $\rightarrow$ coherent GP(I), GP(II) zones

$\rightarrow$ semicoherent $\eta^{\prime} \rightarrow$ incoherent $\eta-\left(\mathrm{MgZn}_{2}\right)$ or $\mathrm{T}-\left(\mathrm{Al}_{2} \mathrm{Mg}_{3} \mathrm{Zn}_{3}\right)$

The casting of $\mathrm{AlZnMg}(\mathrm{Cu})$ alloys is known to be difficult. The large solidification interval and complex solidification morphology favor the formation of hot cracks. High cooling rates, as in gravity die casting or high-pressure die casting, can further increase the risk of hot cracking compared to sand casting. ${ }^{13,14}$

In this work, secondary $\mathrm{AlZnMg}(\mathrm{Cu})$ die-cast alloys are developed using thermodynamic simulations and casted into experimental tests. Then, the mechanical properties and microstructures of the materials are analyzed.

\section{Experimental Methods}

The selected alloys must simultaneously achieve casting, mechanical, and corrosion properties; therefore, the material development was supported by thermodynamic simulations. In those calculations, solidification processes and phase compositions of the materials were simulated (Table 1). With the selected $\mathrm{Zn} / \mathrm{Mg}$ ratios, the formation of $\mathrm{T}-\left(\mathrm{Al}_{2} \mathrm{Mg}_{3} \mathrm{Zn}_{3}\right)$ was forced; therefore, the copper contents had to be adjusted to the lower copper solubility of the $\mathrm{T}-\left(\mathrm{Al}_{2} \mathrm{Mg}_{3} \mathrm{Zn}_{3}\right)$ phase (Table 2$)$. As secondary alloys, these materials also contain iron, silicon, chromium, and manganese. The content of these accompanying elements in $\mathrm{AlZn} 4 \mathrm{Mg} 3 \mathrm{Cu}(\mathrm{Fe})$ is twice as high as in $\mathrm{AlZn} 5 \mathrm{Mg} 4 \mathrm{Cu}$. This variation should give information about the influence

Table 1. Nominal Compositions of the Experimental Alloys in wt.\%

\begin{tabular}{lllllllll}
\hline Alloy & $\mathrm{Zn}$ & $\mathrm{Mg}$ & $\mathrm{Cu}$ & $\mathrm{Si}$ & $\mathrm{Fe}$ & $\mathrm{Mn}$ & $\mathrm{Cr}$ & $\mathrm{Ti}$ \\
\hline AlZn4Mg3Cu$(\mathrm{Fe})$ & 4.0 & 3.0 & 0.5 & $0.4-0.6$ & $0.6-0.8$ & $0.6-0.8$ & $0.2-0.4$ & 0.25 \\
AlZn5Mg4Cu & 5.0 & 4.0 & 0.5 & $0.2-0.4$ & $0.2-0.4$ & $0.2-0.4$ & $0.1-0.2$ & - \\
\hline
\end{tabular}

Table 2. Evaluation and Grain Refining Elements of the Experimental Alloys in wt.\%

\begin{tabular}{lll}
\hline Alloy & Evaluation & Grain refining elements \\
\hline AlZn4Mg3Cu(Fe) & $\mathrm{Zn}+\mathrm{Mg}=7.0$ & $0.25 \mathrm{Ti}$ \\
& $\mathrm{Zn} / \mathrm{Mg}=1.33$ & \\
& $\mathrm{Fe}+\mathrm{Si}+\mathrm{Cr}+\mathrm{Mn}=2.2$ & $0.1 \mathrm{TiB}_{2}$ \\
$\mathrm{Zn}+\mathrm{Mg}=9.0$ & \\
& $\mathrm{Zn} / \mathrm{Mg}=1.25$ \\
& $\mathrm{Fe}+\mathrm{Si}+\mathrm{Cr}+\mathrm{Mn}=1.05$ & \\
\hline
\end{tabular}

Table 3. Actual Compositions of the Experimental Alloys in wt.\%

\begin{tabular}{lllllllll}
\hline Alloy & $\mathrm{Zn}$ & $\mathrm{Mg}$ & $\mathrm{Cu}$ & $\mathrm{Si}$ & $\mathrm{Fe}$ & $\mathrm{Mn}$ & $\mathrm{Cr}$ & $\mathrm{Ti}$ \\
\hline AlZn4Mg3Cu(Fe) & 4.0 & 3.09 & 0.5 & 0.57 & 0.85 & 0.79 & 0.35 & 0.19 \\
AlZn5Mg4Cu & 5.39 & 4.16 & 0.53 & 0.31 & 0.31 & 0.31 & 0.1 & - \\
\hline
\end{tabular}


Table 4. Casting Parameters

\begin{tabular}{ll}
\hline Casting temperature $\left[{ }^{\circ} \mathrm{C}\right]$ & $770 \pm 5$ \\
Mold temperature $\left[{ }^{\circ} \mathrm{C}\right]$ & $300 \pm 5$ \\
Mold filling speed $[\mathrm{m} / \mathrm{s}]$ & 2.0 \\
Mold filling pressure $[\mathrm{bar}]$ & 156.0 \\
Cooling time $[\mathrm{s}]$ & 8.0 \\
\hline
\end{tabular}

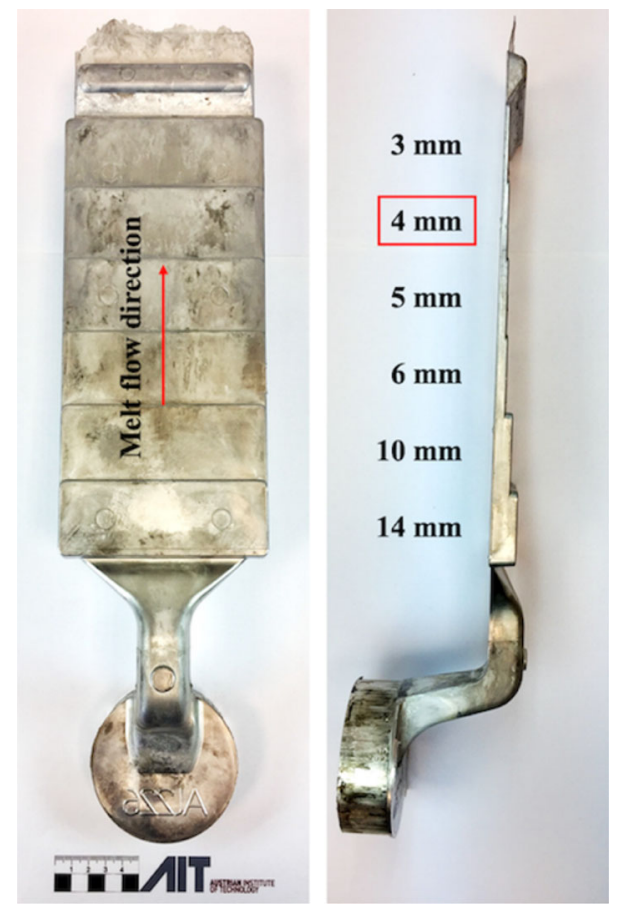

Figure 1. Test specimen from the die castings.

of these elements on the phase formation. For grain refinement, titanium was used in $\mathrm{AlZn} 4 \mathrm{Mg} 3 \mathrm{Cu}(\mathrm{Fe})$, and $\mathrm{TiB}_{2}$ was used in $\mathrm{AlZn} 5 \mathrm{Mg} 4 \mathrm{Cu}$ to highlight the effectiveness of different grain refining elements.

The alloys were prepared in a crucible furnace, and the chemical compositions were checked by a spectrometer analysis (Table 3). Then, the melts were degassed with argon for $45 \mathrm{~min}$. The effectiveness of this treatment was verified by the vacuum density test. For this purpose, the samples were solidified under atmospheric (atm) and

Table 5. Heat Treatment Parameters

\begin{tabular}{lll}
\hline Heat treatment & Temperature in ${ }^{\circ} \mathrm{C}$ & Time in h \\
\hline Solution heat treatment & $390 \pm 4$ & 2 \\
T6* & $160 \pm 3$ & 10 \\
T73-1st stage & $120 \pm 3$ & 24 \\
T73-2nd stage & $160 \pm 3$ & 5 \\
\hline
\end{tabular}

vacuum (80 mbar) pressure, from which the apparent densities and density index could be determined. In each case, a value of approximately 2.0 was achieved. The die casting tests were performed with a cold-chamber die casting machine (Table 4). The process was supported by a linear dosing system. An oil emulsion was used as the mold release agent and applied by a spraying equipment. A plate with different wall thicknesses of 3-14 mm served as a mold, but the material characterization was based on the $4 \mathrm{~mm}$ sections, as shown in Figure 1. To prevent hot cracks, the mold was tempered at a temperature of $300{ }^{\circ} \mathrm{C}$ by oil heating units. The die casting tests were performed without vacuum support.

Then, the castings were subjected to T6 and T73 heat treatment. $\mathrm{AlZnMg}(\mathrm{Cu})$ alloys are usually solutionized at temperatures between 460 and $480{ }^{\circ} \mathrm{C}$ for about $10 \mathrm{~h}$. However, for die-cast products, the risk of blistering must be considered, and therefore, a lower temperature is preferred. To determine the optimum solutionizing temperature, preliminary tests were performed. Since blistering was observed at higher temperatures, it was finally set at $390{ }^{\circ} \mathrm{C}$. After a short solutionizing of $2 \mathrm{~h}$, the samples were immediately quenched in water at room temperature. Since long annealing and aging times are energy-consuming and uneconomical, T6 artificial aging was performed at high temperature with short aging time (Table 5), which resulted in an industrially attractive heat treatment (T6*). The T73 artificial aging process was based on literature references. ${ }^{2}$ After the artificial aging treatment, 6 tensile specimens per alloy and condition were prepared according to DIN 50125:2016-12-E3 × $8 \times 30$. The tests were performed in accordance with DIN EN ISO 6892-1:2017-02. For the metallographic analysis, the samples were taken from the centers transverse to the melt flow direction, ground with $\mathrm{SiC}$ paper, diamond polished, and finally polished with OP-S. Then, the microstructures could be examined with an optical microscope (OM). In addition, 5 hardness measurements were performed using DIN EN ISO 6507-1:2018-07. A more detailed microstructural analysis was executed with the scanning electron microscope (SEM), which was equipped with an energy-dispersive spectroscopy (EDS) detector. For this analysis, an accelerating voltage of $20 \mathrm{kV}$ and the contrast of backscattered electrons were used. Finally, after electrolytic Barker etching, the grain sizes were evaluated in polarized light using the optical microscope. The electrolyte for etching consisted of $50 \% \mathrm{HBF}_{4}$ acid with distilled water in a ratio of 1:20 using a voltage of $40 \mathrm{~V}$, a flow rate of $12 \mathrm{l} / \mathrm{min}$, and an etching time of $50 \mathrm{~s}$.

\section{Results and Discussion}

Since solidification conditions in high-pressure die casting allow extremely limited diffusion, the simulations could be calculated using the Scheil-Gulliver model. Therefore, no 

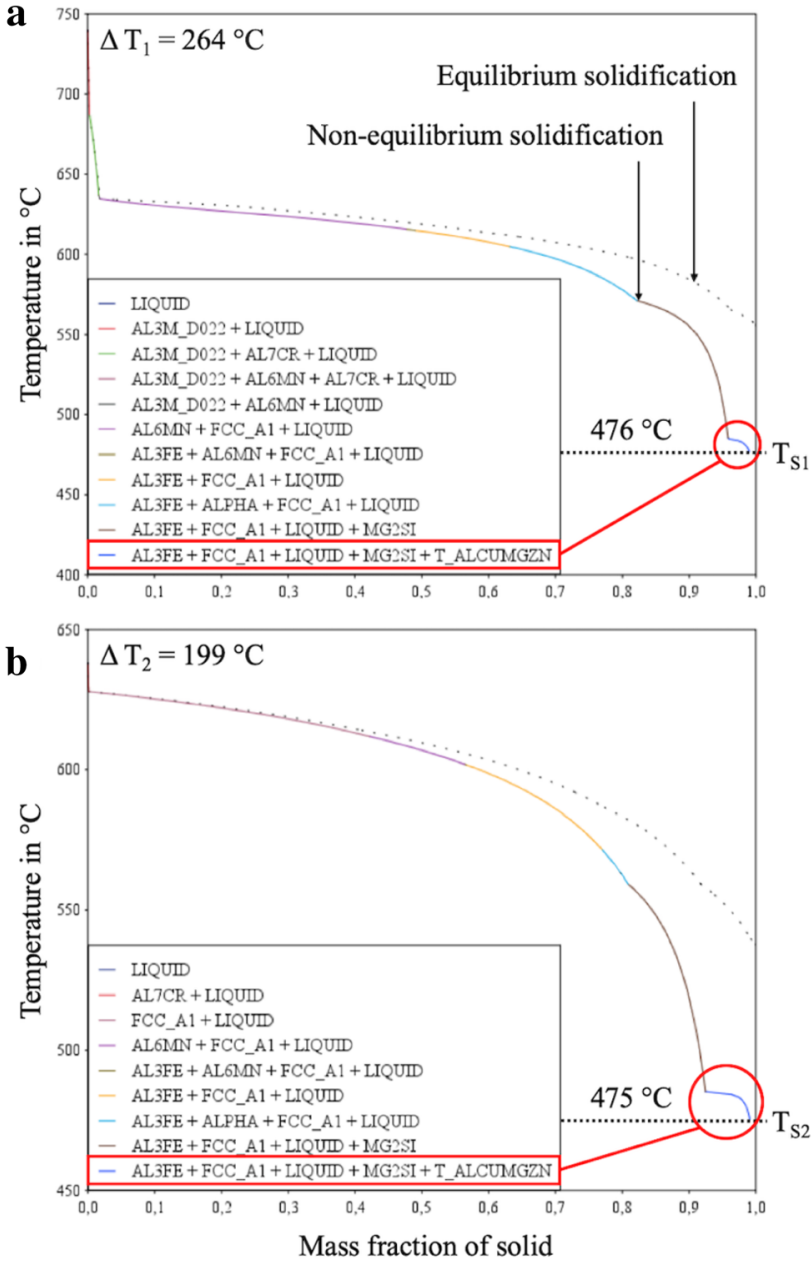

Figure 2. Exemplary calculations of non-equilibrium phases according to Scheil-Gulliver, (a) AIZn4Mg3Cu(Fe) and (b) AIZn5Mg4Cu.

Table 6. Calculation of 0.5 wt. $\%$ of Copper in an Equilibrium State at $300^{\circ} \mathrm{C}$ in $\%$

\begin{tabular}{lll}
\hline Phase & AlZn4Mg3Cu(Fe) & AlZn5Mg4Cu \\
\hline $\mathrm{T}-\left(\mathrm{Al}_{2} \mathrm{Mg}_{3} \mathrm{Zn}_{3}\right)$ & 54.63 & 96.4 \\
$\eta-\left(\mathrm{MgZn}{ }_{2}\right)$ & 20.66 & - \\
$\alpha_{\mathrm{Al}}$ & 15.71 & 3.35 \\
$\mathrm{Al}_{6} \mathrm{Mn}$ & 9.0 & 0.24 \\
\hline
\end{tabular}

diffusion is assumed in the solid phase, but infinitely fast diffusion in the liquid phase and an equilibrium at the solid-liquid interface. ${ }^{15,16}$ The calculations show a delay of complete solidification due to the formation of segregations, which increases the risk of hot cracking. According to Scheil-Gulliver, solidification ends at approximately

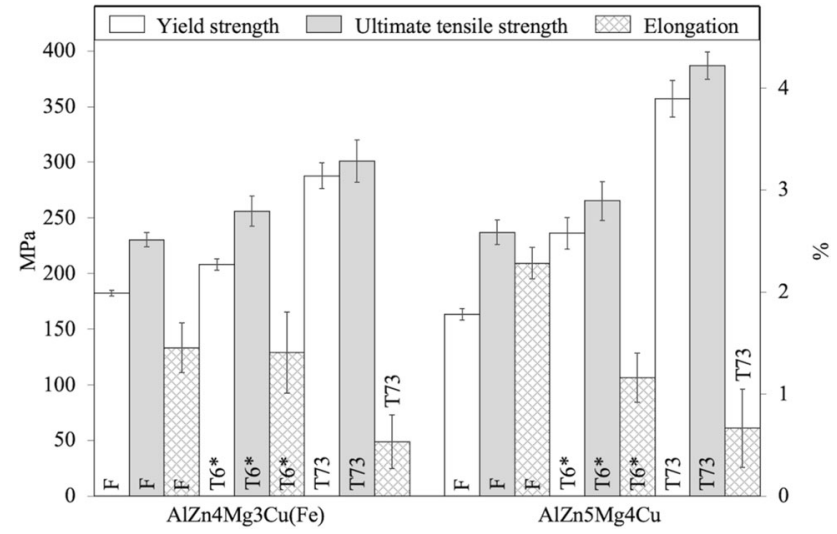

Figure 3. Mechanical properties: yield strength, ultimate tensile strength, and elongation of the tested alloys.

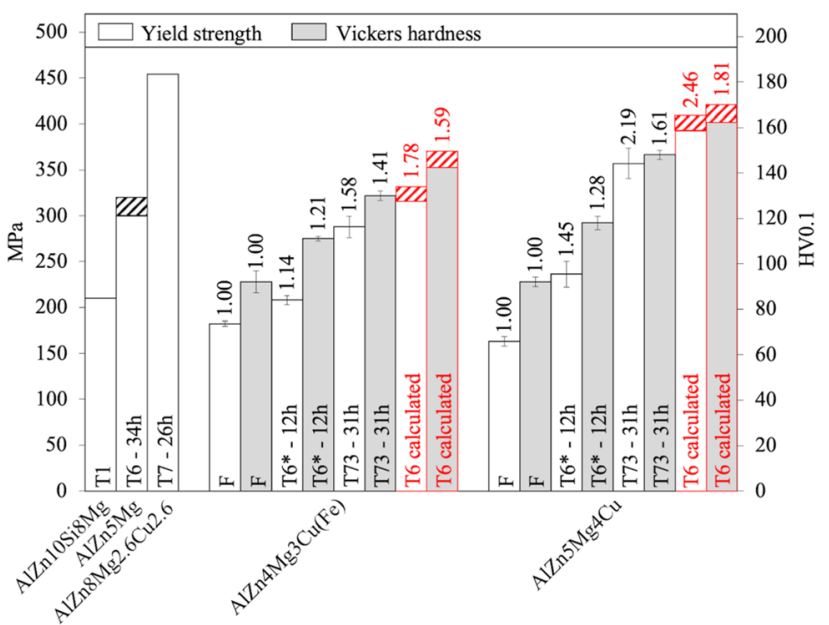

Figure 4. Mechanical properties: comparative analysis of yield strength and hardness values with heat treatment times and growth factors. ${ }^{17-19}$

Table 7. Heat Treatment Parameters of the Reference Alloys AIZn5Mg and AIZn8Mg2.6Cu2.6 ${ }^{18,19}$

\begin{tabular}{lllll}
\hline Heat treatment & \multicolumn{2}{l}{ AlZn5Mg } & \multicolumn{3}{l}{ AlZn8Mg2.6Cu2.6 } \\
\hline Solution heat treatment & $520{ }^{\circ} \mathrm{C}$ & $10 \mathrm{~h}$ & $460{ }^{\circ} \mathrm{C}$ & $10 \mathrm{~h}$ \\
T6 & $120^{\circ} \mathrm{C}$ & $24 \mathrm{~h}$ & - & - \\
T73-1st stage & - & - & $110^{\circ} \mathrm{C}$ & $8 \mathrm{~h}$ \\
T73-2nd stage & - & - & $160^{\circ} \mathrm{C}$ & $8 \mathrm{~h}$ \\
\hline
\end{tabular}

$475{ }^{\circ} \mathrm{C}$ with the formation of a complex eutectic of $\mathrm{Al}_{3} \mathrm{Fe}$, $\mathrm{Mg}_{2} \mathrm{Si}, \mathrm{T}-(\mathrm{AlCuMgZn})$, and aluminum. The alloy $\mathrm{AlZn} 4 \mathrm{Mg} 3 \mathrm{Cu}(\mathrm{Fe})$, as shown in Figure 2a, clearly shows a 
lower proportion of this eutectic than $\mathrm{AlZn} 5 \mathrm{Mg} 4 \mathrm{Cu}$, as shown in Figure 2b, which is due to higher zinc and magnesium levels in the second variant. According to these simulations, the $\eta-\left(\mathrm{MgZn}_{2}\right)$ phase does not occur in either variants. Furthermore, the solidification interval of $\mathrm{AlZn} 4 \mathrm{Mg} 3 \mathrm{Cu}(\mathrm{Fe})$ is approximately $65^{\circ} \mathrm{C}$ higher than of $\mathrm{AlZn} 5 \mathrm{Mg} 4 \mathrm{Cu}$. The higher proportion of the eutectic phase and lower solidification interval could benefit the castability of the alloy $\mathrm{AlZn} 5 \mathrm{Mg} 4 \mathrm{Cu}$.

As mentioned, the copper distribution has a significant effect on the material properties of $\operatorname{AlZnMg}(\mathrm{Cu})$ alloys. Therefore, the dissolution behavior of the element was tested by an equilibrium simulation at $300{ }^{\circ} \mathrm{C}$ (Table 6). In the $\mathrm{AlZn} 5 \mathrm{Mg} 4 \mathrm{Cu}$ variant, copper is almost completely bound in the T-phase, which is consistent with the objective of alloy development. In $\mathrm{AlZn} 4 \mathrm{Mg} 3 \mathrm{Cu}(\mathrm{Fe})$, only

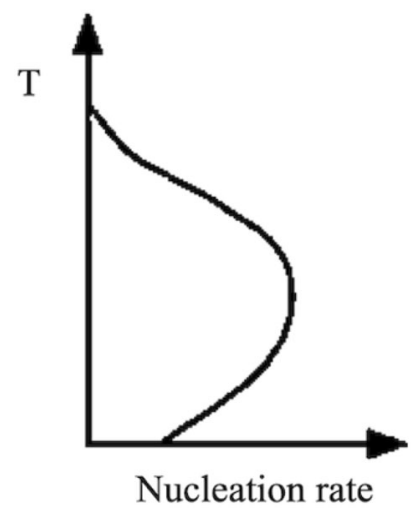

Figure 5. Schematic graph of the temperature dependency of the nucleation rate in precipitation strengthening. ${ }^{22}$ approximately half of the copper is bound in the T-phase, and the remainder is dissolved in $\mathrm{Al}_{6} \mathrm{Mn}, \alpha_{\mathrm{Al}}$, and $\eta$ $\left(\mathrm{MgZn}_{2}\right)$. The higher silicon content in $\mathrm{AlZn} 4 \mathrm{Mg} 3 \mathrm{Cu}(\mathrm{Fe})$ provides a higher proportion of $\mathrm{Mg}_{2} \mathrm{Si}$; thus, a decrease in free magnesium is induced. Since this is accompanied by an increase in $\mathrm{Zn} / \mathrm{Mg}$ ratio, the formation of the $\eta$-phase is promoted. The distribution of copper into several phases should significantly affect the material properties, which can be very critical with regard to corrosion.

The experimental tests can be summarized by two main points. First, it has been possible to process two extremely difficultly casted alloys by high-pressure die casting with no hot cracks observed in any product. Second, good mechanical properties were achieved in an energy-efficient manner, as shown in Figure 3. Although the mechanical properties of both alloys are similar as cast and in the T6* condition, the $\mathrm{T} 73$ variant of the alloy $\mathrm{AlZn} 5 \mathrm{Mg} 4 \mathrm{Cu}$ shows a significantly higher strength. Furthermore, the elongation of $\mathrm{AlZn} 5 \mathrm{Mg} 4 \mathrm{Cu}$ as cast is higher than that of $\mathrm{AlZn} 4 \mathrm{Mg} 3 \mathrm{Cu}(\mathrm{Fe})$. However, in the artificially aged conditions, the elongation of both materials drops to the same level. For a comparison, the standard die-cast alloy AlZn10Si8 $\mathrm{Mg}^{17}$ and artificially aged alloys $\mathrm{AlZn} 5 \mathrm{Mg}^{18}$ and $\mathrm{AlZn} 8 \mathrm{Mg} 2.6 \mathrm{Cu} 2.6^{19}$ are used, as shown in Figure 4. These reference alloys were not processed by high-pressure die casting but have higher contents of alloying elements or were subjected to energy-intensive heat treatment procedures (Table 7). The die-cast alloys $\mathrm{AlZn} 4 \mathrm{Mg} 3 \mathrm{Cu}(\mathrm{Fe})$ and $\mathrm{AlZn} 5 \mathrm{Mg} 4 \mathrm{Cu}$ achieve yield strengths of $208 \mathrm{MPa}$ and $236 \mathrm{MPa}$, respectively, by an energy- and time-saving T6* aging. With a heat treatment time of only $12 \mathrm{~h}$, a growth factor of 1.14 and 1.45 is realized. By using the T73 variant, the yield strength increases to $288 \mathrm{MPa}(1.58)$ and $357 \mathrm{MPa}$ (2.19), respectively. This strength is $10-15 \%$

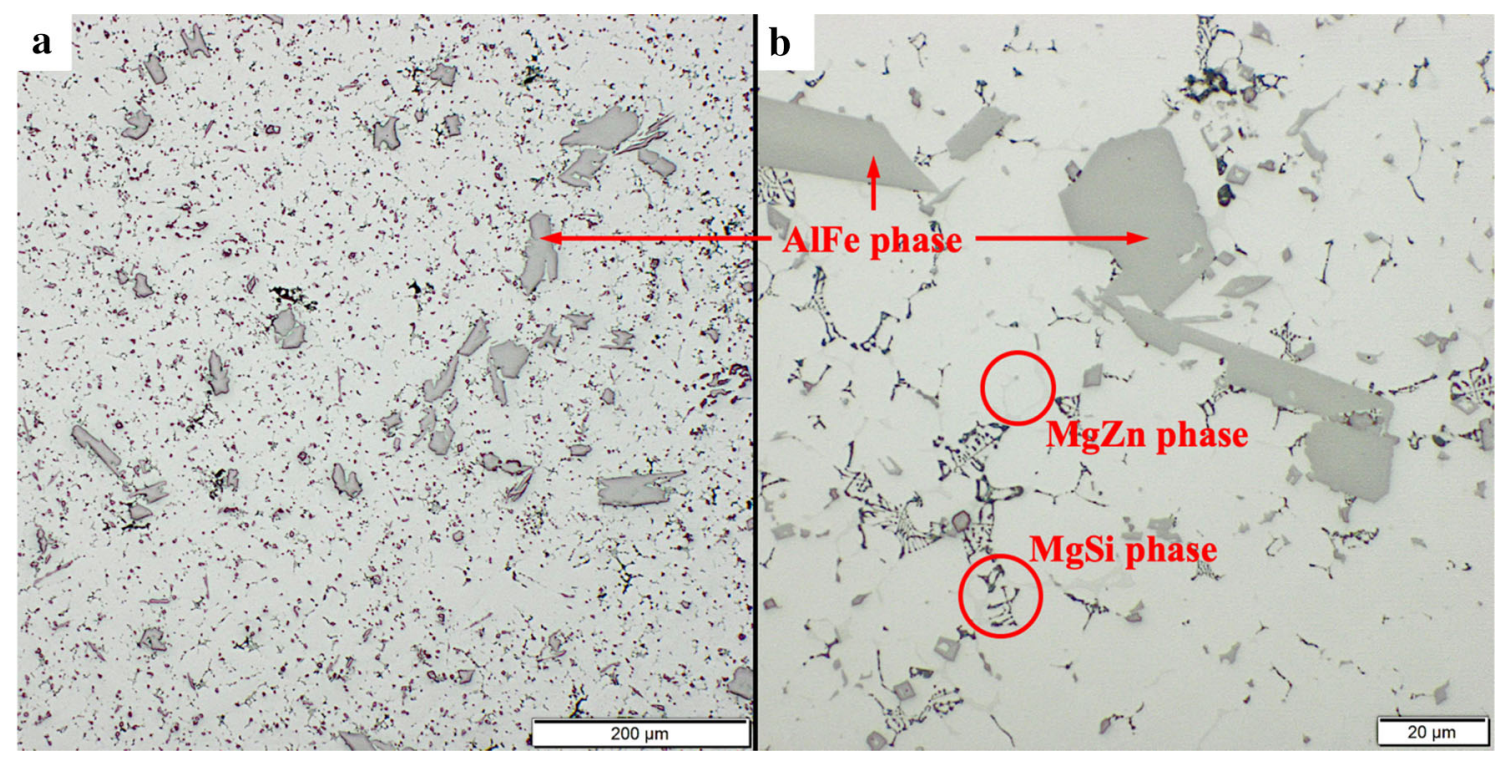

Figure 6. OM: microstructure analysis of $A / Z n 4 M g 3 C u(F e)$ as cast at (a) low and (b) high magnification. 
lower than the maximum strength of an optimal T6 condition. ${ }^{20}$ The contents of zinc and magnesium increase the solid solution strengthening and precipitation strengthening; hence, the higher hardening potential of $\mathrm{AlZn} 5 \mathrm{Mg} 4 \mathrm{Cu}$ can be explained. Since there is an alloy-specific temperature dependency of the nucleation rate, at low temperatures, a multitude of finely distributed, small, coherent precipitates are formed and at high temperatures, there are rare, coarse, incoherent particles, as shown in Figure 5. ${ }^{21,22}$ According to this, the maximum strength values are achieved at comparatively low aging temperatures and long aging times. For example, the wrought alloy 7075 attains its maximum strength at a temperature of $120{ }^{\circ} \mathrm{C}$ and an aging time of $24 \mathrm{~h}^{23}$ At higher temperatures, the achievable strengths are lower, but the aging time is significantly reduced. ${ }^{2,24}$ As a result, the control of both temperature and time is extremely important. This approach has great economic importance. However, the combination of high temperature and short aging time explains the T6* aging, which does not present the peak hardness of the alloys. During T73 aging, small, coherent precipitates are formed in the 1st stage at low temperature but grow to partially
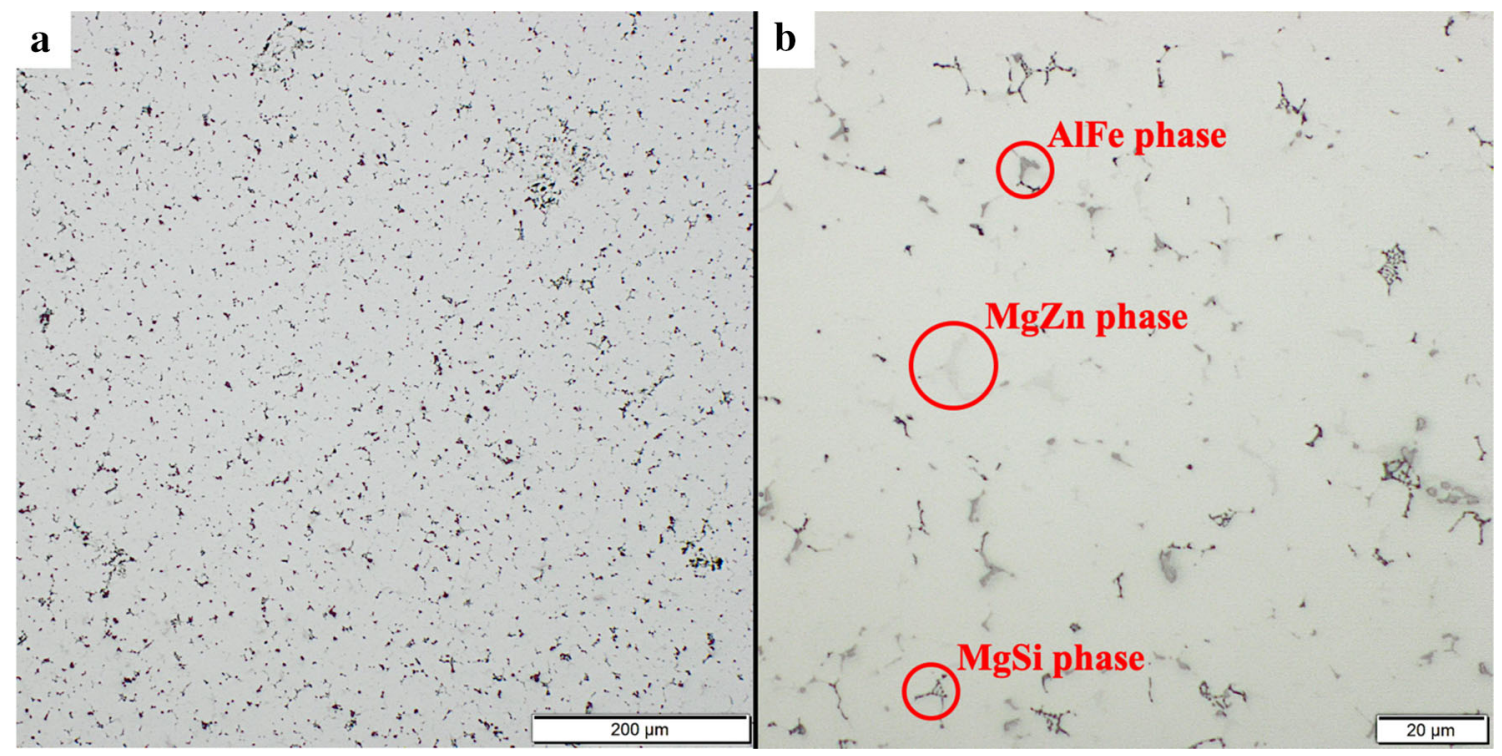

Figure 7. OM: microstructure analysis of AlZn5Mg4Cu as cast at (a) low and (b) high magnification.

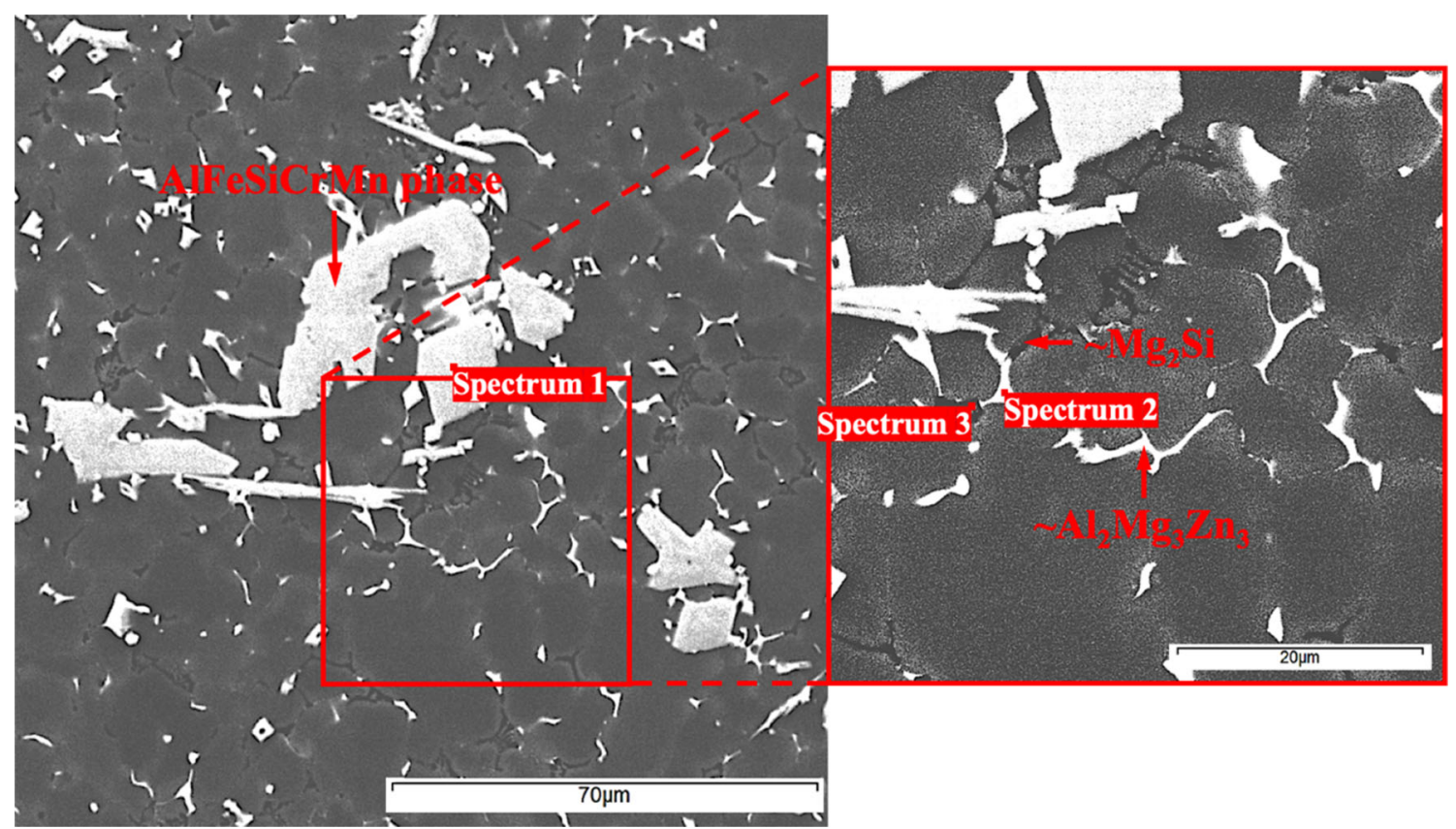

Figure 8. SEM: AIZn4Mg3Cu(Fe) as cast, point analysis of an AlFeSiCrMn phase (Spectrum 1), T$\left(\mathrm{Al}_{2} \mathrm{Mg}_{3} \mathrm{Zn}_{3}\right)$ phase (Spectrum 2), and $\sim \mathrm{Mg}_{2}$ Si phase (Spectrum 3) in at.\%. 

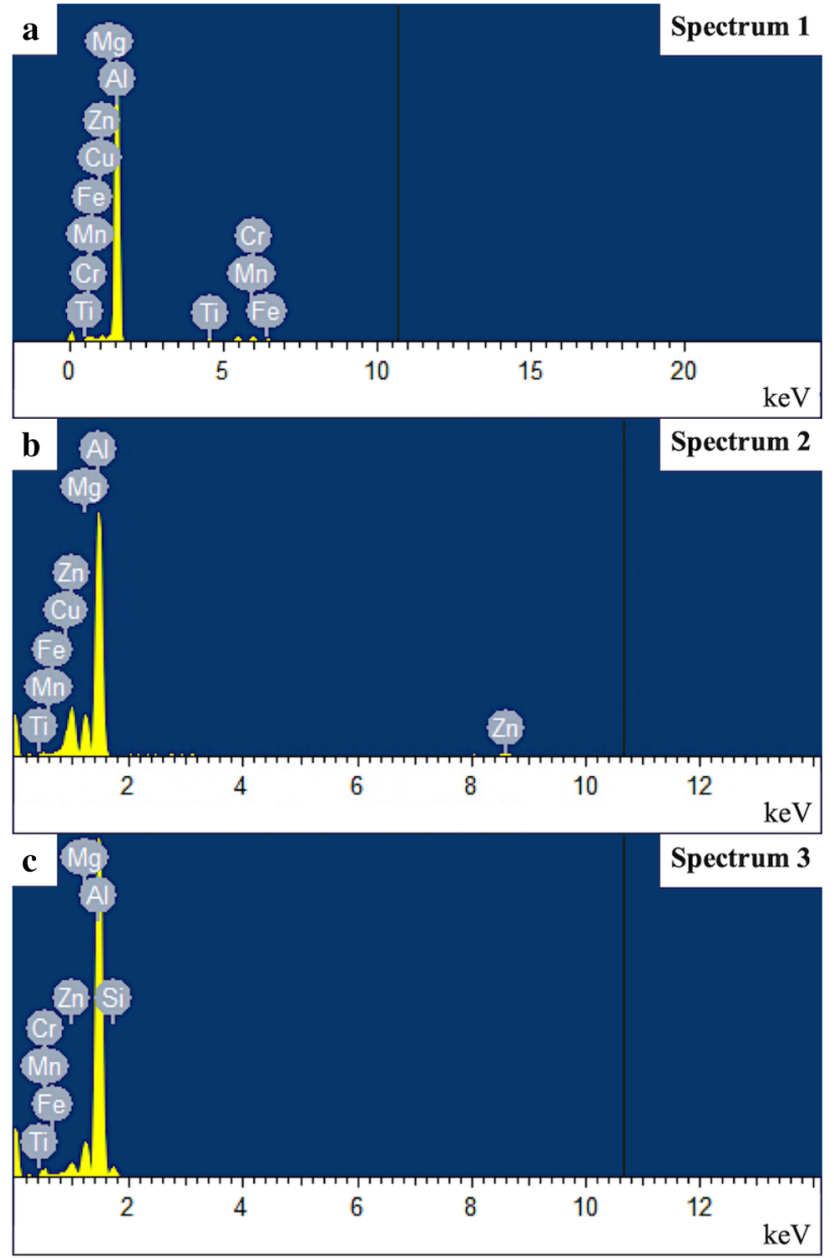

Figure 9. EDS point analysis: (a) AIFeSiCrMn phase (Spectrum 1), (b) T-(Al2 $\left.\mathrm{Mg}_{3} \mathrm{Zn} \mathrm{n}_{3}\right)$ phase (Spectrum 2), and (c) $\sim \mathrm{Mg}_{2} \mathrm{Si}$ phase (Spectrum 3) in AlZn4Mg3Cu(Fe) as cast.

coherent particles in the 2nd stage. Therefore, the T73 condition is described as overaged. Although the T73 heat treatment process is energy- and time-intensive, it is particularly relevant for $\mathrm{AlZnMg}(\mathrm{Cu})$ alloys, since the highest resistance to stress corrosion cracking is achieved in this condition.

In optical microscopic analysis, $\mathrm{AlZn} 4 \mathrm{Mg} 3 \mathrm{Cu}(\mathrm{Fe})$ shows block-like particles, which indicate AlFe compounds, as shown in Figure 6. Furthermore, the eutectic regions are likely to be subdivided into $\mathrm{MgZn}$ and $\mathrm{MgSi}$ phases. However, the microstructure of the variant $\mathrm{AlZn} 5 \mathrm{Mg} 4 \mathrm{Cu}$ is more homogeneous without coarse particles, as shown in Figure 7. The scanning electron microscopic analysis confirms block-like AlFeSiCrMn phases in AlZn4Mg3$\mathrm{Cu}(\mathrm{Fe})$, as shown in Figure 8, which also contain levels of titanium and copper (Figure 9, Table 8). Although titanium was alloyed to refine $\alpha_{\mathrm{Al}}$ by the formation of $\mathrm{Al}_{3} \mathrm{Ti}$, it is mainly found in the AlFeSiCrMn particles. The solidification simulation provides a possible indication. According to this result, $\mathrm{Al}_{3} \mathrm{Ti}, \mathrm{Al}_{7} \mathrm{Cr}$, and $\mathrm{Al}_{6} \mathrm{Mn}$ form a complex phase before the solidification of $\alpha$-aluminum starts, which can affect the grain refinement. Other works have shown an interaction between chromium and titanium ${ }^{25}$ and a grain coarsening effect caused by chromium. ${ }^{26}$ In any case, the effect of iron-containing particles on the mechanical properties of aluminum alloys has been widely published: With an iron increase of $0.15 \%$, the yield strength is not affected or can even be slightly enhanced ${ }^{27}$, but the elongation is reduced by more than $35 \% .^{28,29}$ This fact can explain the elongation ratios of the tested alloys. Furthermore, the eutectics show significant levels of zinc and magnesium; hence, $\sim \mathrm{T}-\left(\mathrm{Al}_{2} \mathrm{Mg}_{3} \mathrm{Zn}_{3}\right)$ precipitates can be identified. In addition, other eutectics such as $\sim \mathrm{Mg}_{2} \mathrm{Si}$ phases are detected. The frequent occurrence of $\sim \mathrm{T}$ $\left(\mathrm{Al}_{2} \mathrm{Mg}_{3} \mathrm{Zn}_{3}\right)$ and $\sim \mathrm{Mg}_{2} \mathrm{Si}$ is consistent with the simulative results and literature data. ${ }^{30}$ The characterization of $\mathrm{AlZn} 5 \mathrm{Mg} 4 \mathrm{Cu}$ shows no coarse AlFeSiCrMn phases like no other AlFeCr particles, as shown in Figure 10. Moreover, $\sim \mathrm{Mg}_{2} \mathrm{Si}$ phases are detected but less frequently than in $\mathrm{AlZn} 4 \mathrm{Mg} 3 \mathrm{Cu}(\mathrm{Fe})$, as shown in Figure $11 \mathrm{a}$, due to the reduction in iron, manganese, chromium, and silicon. In addition, a higher proportion of eutectic regions can be identified in $\mathrm{AlZn} 5 \mathrm{Mg} 4 \mathrm{Cu}$, which is consistent with the thermodynamic calculations. Besides $\sim \mathrm{T}-\left(\mathrm{Al}_{2} \mathrm{Mg}_{3} \mathrm{Zn}_{3}\right)$, as shown in Figure 11b, other complex eutectic compositions with iron, manganese, and silicon contents are detected using the X-ray analysis (Figure 12, Table 9). Since less zinc, magnesium, and copper are located in these areas, a partial copper supersaturation and the formation of $\sim \mathrm{Al}_{7} \mathrm{Cu}_{2} \mathrm{Fe}$ phases may occur, as shown in Figure 11c. These particles also contain small amounts of manganese and have been known before. ${ }^{31,32}$

The electrolytic Barker etch allows a predication about the grain structures of the materials. In $\mathrm{AlZn} 4 \mathrm{Mg} 3 \mathrm{Cu}(\mathrm{Fe})$, as shown in Figure 13, the dendritic structures and grains are more inhomogeneous and tend to be larger than those in $\mathrm{AlZn} 5 \mathrm{Mg} 4 \mathrm{Cu}$, as shown in Figure 14. On the one hand, the appliance of different grain refining elements must be considered. On the other hand, the findings of this work confirm that the formation of titanium-containing AlFe$\mathrm{SiCrMn}$ precipitates adversely affects the grain refinement of $\alpha_{\mathrm{Al}}$. Thus, $\mathrm{TiB}_{2}$ may cause a more effective grain refinement under given conditions with increased accompanying element content. The effect of the grain size on mechanical properties is generally described by Hall-Petch relationship. This equation explains the interaction of dislocations with grain boundaries; hence, it explains a higher strength at smaller grain sizes. ${ }^{33}$ Hall-Petch is particularly 
Table 8. EDS Point Analysis of AlZn4Mg3Cu(Fe) As Cast in at.\%

\begin{tabular}{|c|c|c|c|c|c|c|c|c|c|}
\hline & $\mathrm{Al}$ & $\mathrm{Zn}$ & $\mathrm{Mg}$ & $\mathrm{Cu}$ & $\mathrm{Fe}$ & $\mathrm{Cr}$ & $\mathrm{Mn}$ & $\mathrm{Si}$ & $\mathrm{Ti}$ \\
\hline Spectrum 1: AlFeSiCrMn & 85.84 & 1.03 & 1.33 & 0.26 & 1.93 & 3.98 & 4.13 & 0.31 & 1.18 \\
\hline Spectrum 2: $\sim \mathrm{Al}_{2} \mathrm{Mg}_{3} \mathrm{Zn}_{3}$ & 75.34 & 8.20 & 13.35 & 3.12 & - & - & - & - & - \\
\hline Spectrum 3: $\sim \mathrm{Mg}_{2} \mathrm{Si}$ & 85.69 & 1.86 & 8.10 & - & - & - & - & 4.34 & - \\
\hline
\end{tabular}

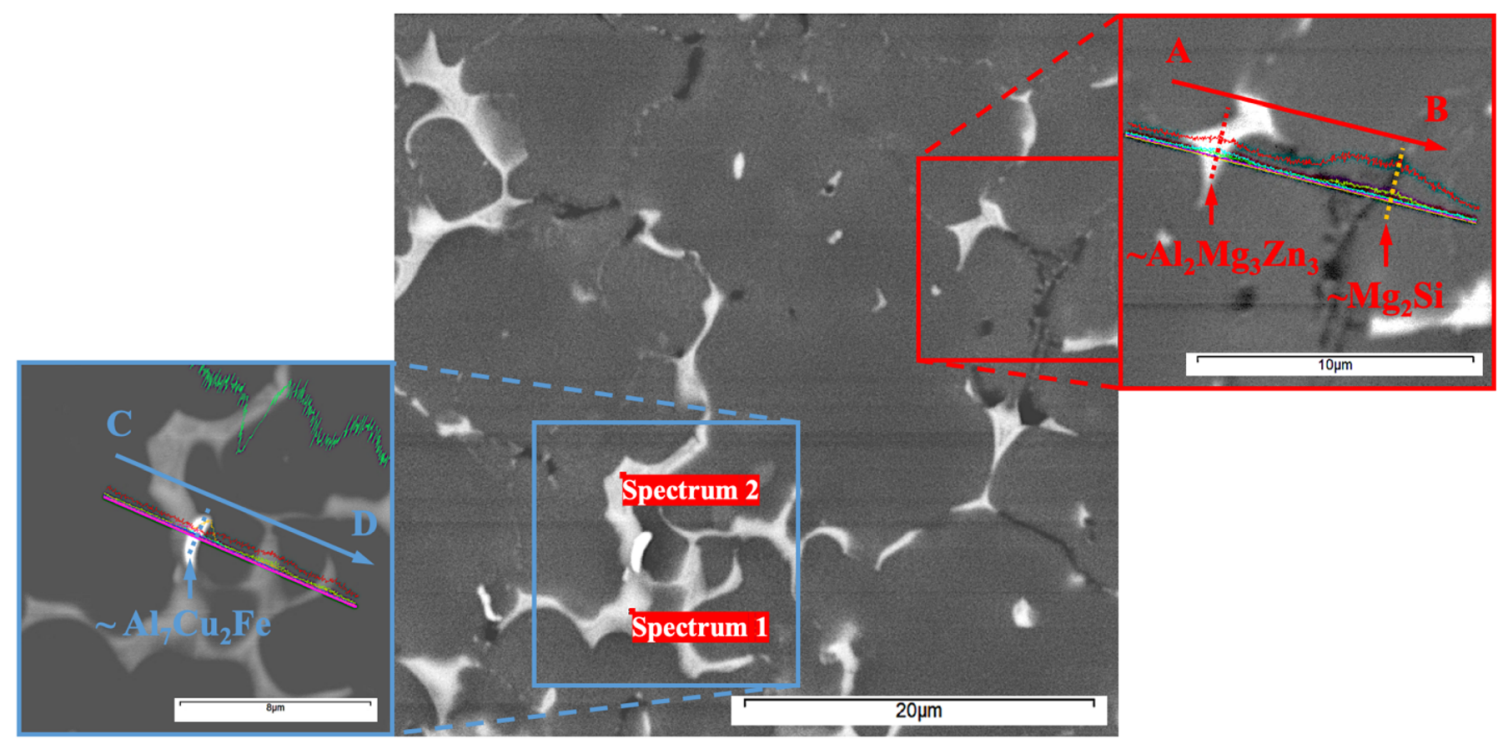

Figure 10. SEM: AIZn5Mg4Cu as cast, point analysis of a complex Fe-Mn-Si-containing eutectic (Spectrum 1), T-(Al $\left.\mathrm{Mg}_{3} \mathrm{Zn}_{3}\right)$ phase (Spectrum 2) in at.\%, line analysis of a $\sim \mathrm{Mg}_{2} \mathrm{Si}$ phase, $\sim \mathrm{T}$ $\left(\mathrm{Al}_{2} \mathrm{Mg}_{3} \mathrm{Zn}_{3}\right)$ phase, and $\sim \mathrm{Al}_{7} \mathrm{Cu}_{2} \mathrm{Fe}$ phase.

valid for wrought alloys, but with dendritic structures and intermetallic phases, there are more complex microstructures in cast alloys. Furthermore, the secondary dendrite arm spacing is greatly important in castings. ${ }^{34}$ Hence, based on AlSi alloys, almost no correlation between grain size and strength was found as cast. ${ }^{35,36}$ However, other studies have shown the opposite and a higher strength with smaller grains. ${ }^{37,38}$ In this case, the yield strength was approximately $10 \%$ higher. This increase was achieved by a grain size reduction from $\sim 600$ to $\sim 100 \mu \mathrm{m}$. Due to precipitation, the difference is higher after artificial aging with approximately $15 \%$. As a consequence, this work also assumes a minor effect of the grain sizes on the mechanical properties. In general, large grains impair feeding, increase the risk of hot cracking, and indirectly downgrade the 

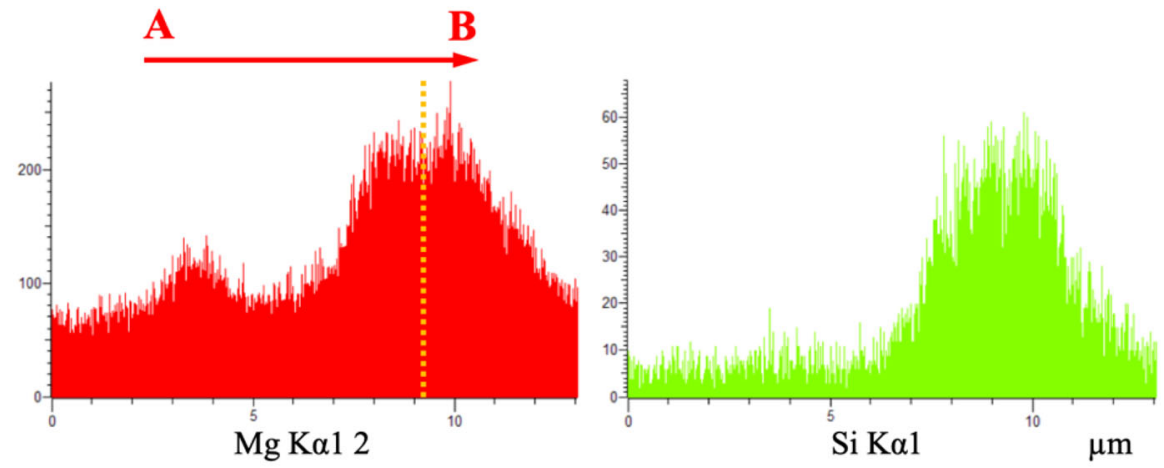

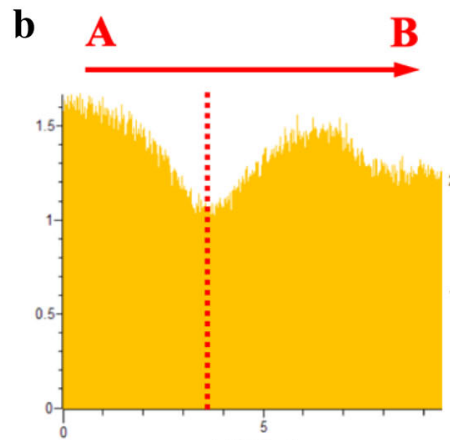

$\mathrm{Al} \mathrm{K} \alpha 1$

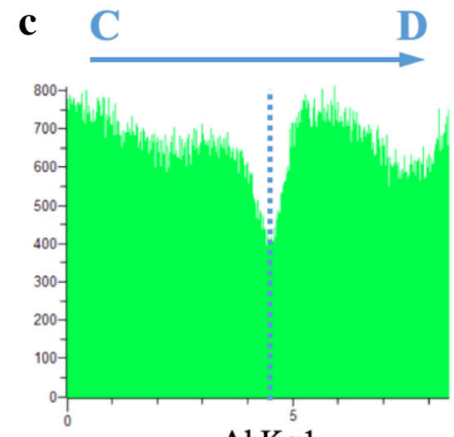

$\mathrm{A} 1 \mathrm{~K} \alpha 1$

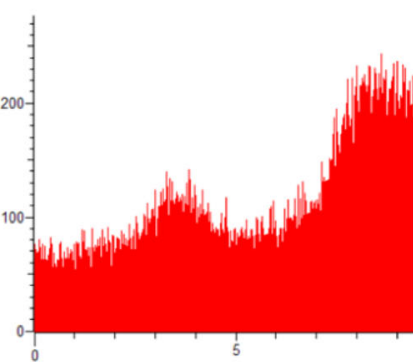

$\operatorname{Mg} \operatorname{K} \alpha 12$

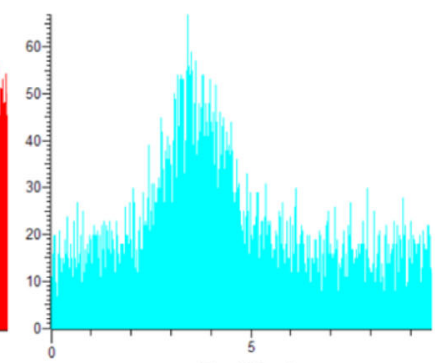

$\mathrm{Zn} \mathrm{K} \alpha 1$

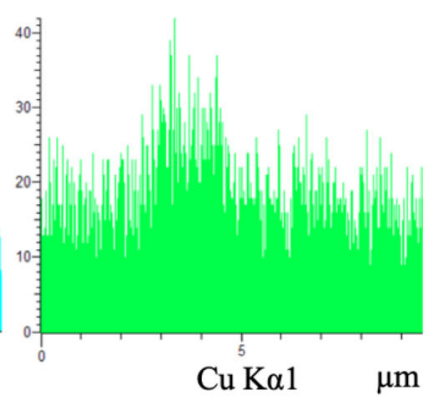

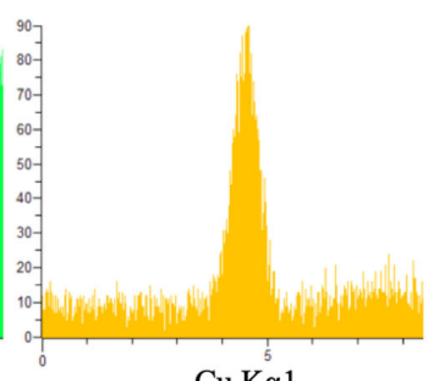

$\mathrm{Cu} \mathrm{K} \alpha 1$

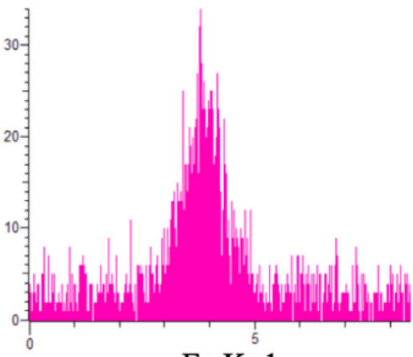

$\mathrm{Fe} \mathrm{K} \alpha 1$

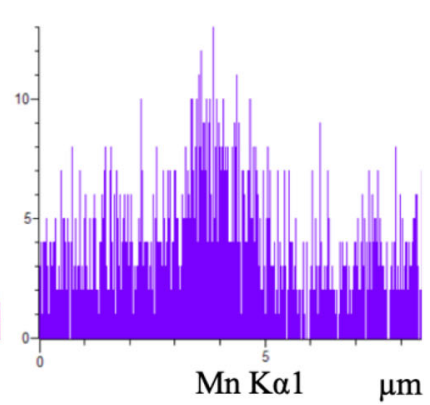

$\mathrm{Mn} \mathrm{K} \alpha 1 \quad \mu \mathrm{m}$

Figure 11. EDS line analysis: (a) $\sim M g_{2} S i$ phase, (b) $\sim T-\left(\mathrm{Al}_{2} \mathrm{Mg}_{3} \mathrm{Zn} \mathrm{n}_{3}\right)$ phase, and (c) $\sim A l_{7} \mathrm{Cu}_{2} \mathrm{Fe}$ phase in $\mathrm{AlZn5Mg4Cu}$ as cast.

mechanical properties due to the coarse distribution of micropores and secondary phases. ${ }^{39,40}$

\section{Summary}

The alloys $\mathrm{AlZn} 4 \mathrm{Mg} 3 \mathrm{Cu}(\mathrm{Fe})$ and $\mathrm{AlZn} 5 \mathrm{Mg} 4 \mathrm{Cu}$ achieved yield strengths of over $200 \mathrm{MPa}$ in the modified T6* state.
Therefore, these materials can be attractive for structural components, where they can challenge standard cast alloys such as AlZn10Si8Mg. Due to the special heat treatment $\mathrm{T} 6 *$, the peak hardness was not achieved in this condition. The mechanical properties in the T73 state were significantly higher. These results were primarily based on the high levels of zinc and magnesium, and a subsequent high 

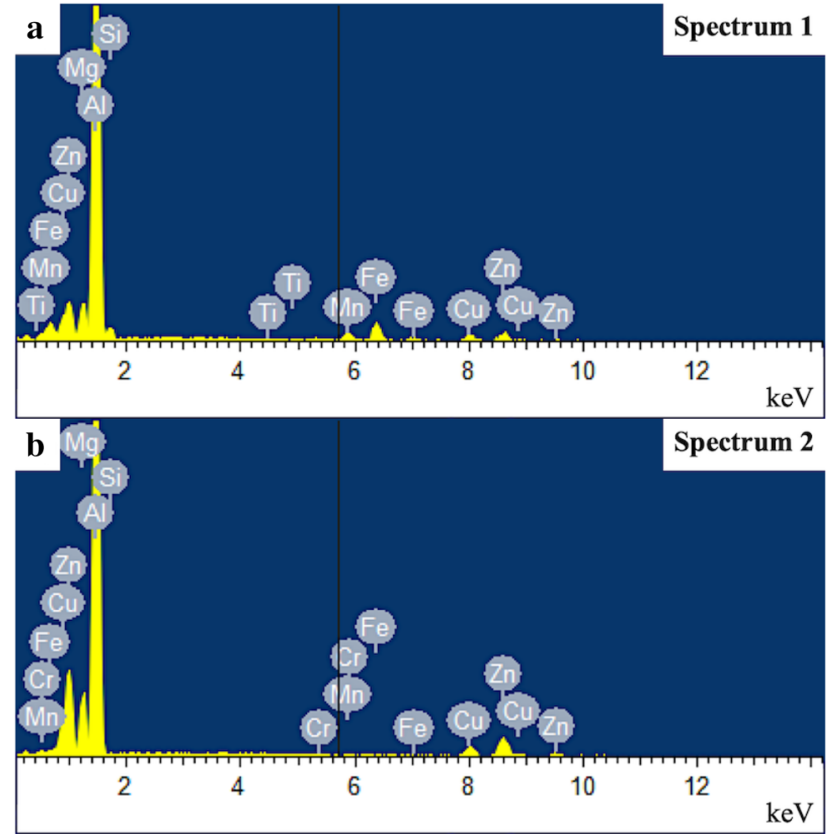

Figure 12. EDS point analysis: (a) Fe-Mn-Si-containing eutectic (Spectrum 1) and (b) $\sim \mathrm{T}-\left(\mathrm{Al}_{2} \mathrm{Mg}_{3} \mathrm{Zn}_{3}\right)$ phase (Spectrum 2) in AIZn5Mg4Cu as cast. level of solid solution strengthening and precipitation strengthening. In addition, the mechanical properties of $\mathrm{AlZn} 4 \mathrm{Mg} 3 \mathrm{Cu}(\mathrm{Fe})$ were influenced by the tendency of larger grains and blocky phases. The analysis shows titanium contents in these particles, which probably affect the grain refinement effect of the element. Due to the observed grain size differences, lower grain boundary strengthening was also assumed in $\mathrm{AlZn} 4 \mathrm{Mg} 3 \mathrm{Cu}(\mathrm{Fe})$.

In this study, difficultly casted $\mathrm{AlZnMg}(\mathrm{Cu})$ alloys could be processed by high-pressure die casting. Moreover, convincing material properties were achieved without costintensive alloying elements using an energy- and time-efficient heat treatment. Hence, this work can provide a trend for the development of such high-strength die-cast alloys. However, to further improve the mechanical properties, the formation of block-like particles and possible interactions with grain refining elements, as in $\mathrm{AlZn} 4 \mathrm{Mg} 3 \mathrm{Cu}(\mathrm{Fe})$, should be avoided. For this purpose, thermodynamic simulations can also be used in the future. Finally, since the corrosion properties are crucial for the appliance of $\operatorname{AlZnMg}(\mathrm{Cu})$ alloys, future work should focus on their investigation.

Table 9. EDS Point Analysis of AlZn5Mg4Cu As Cast in at.\%

\begin{tabular}{llllllllll}
\hline & $\mathrm{Al}$ & $\mathrm{Zn}$ & $\mathrm{Mg}$ & $\mathrm{Cu}$ & $\mathrm{Fe}$ & $\mathrm{Cr}$ & $\mathrm{Mn}$ & $\mathrm{Si}$ & $\mathrm{Ti}$ \\
\hline Spectrum 1: Fe-Mn-Si-containing eutectic & 79.08 & 3.35 & 5.71 & 2.57 & 4.45 & - & 1.74 & 3.10 & - \\
Spectrum 2: $\sim \mathrm{Al}_{2} \mathrm{Mg}_{3} \mathrm{Zn}_{3}$ & 77.12 & 8.38 & 10.99 & 3.51 & - & - & - & - & - \\
\hline
\end{tabular}

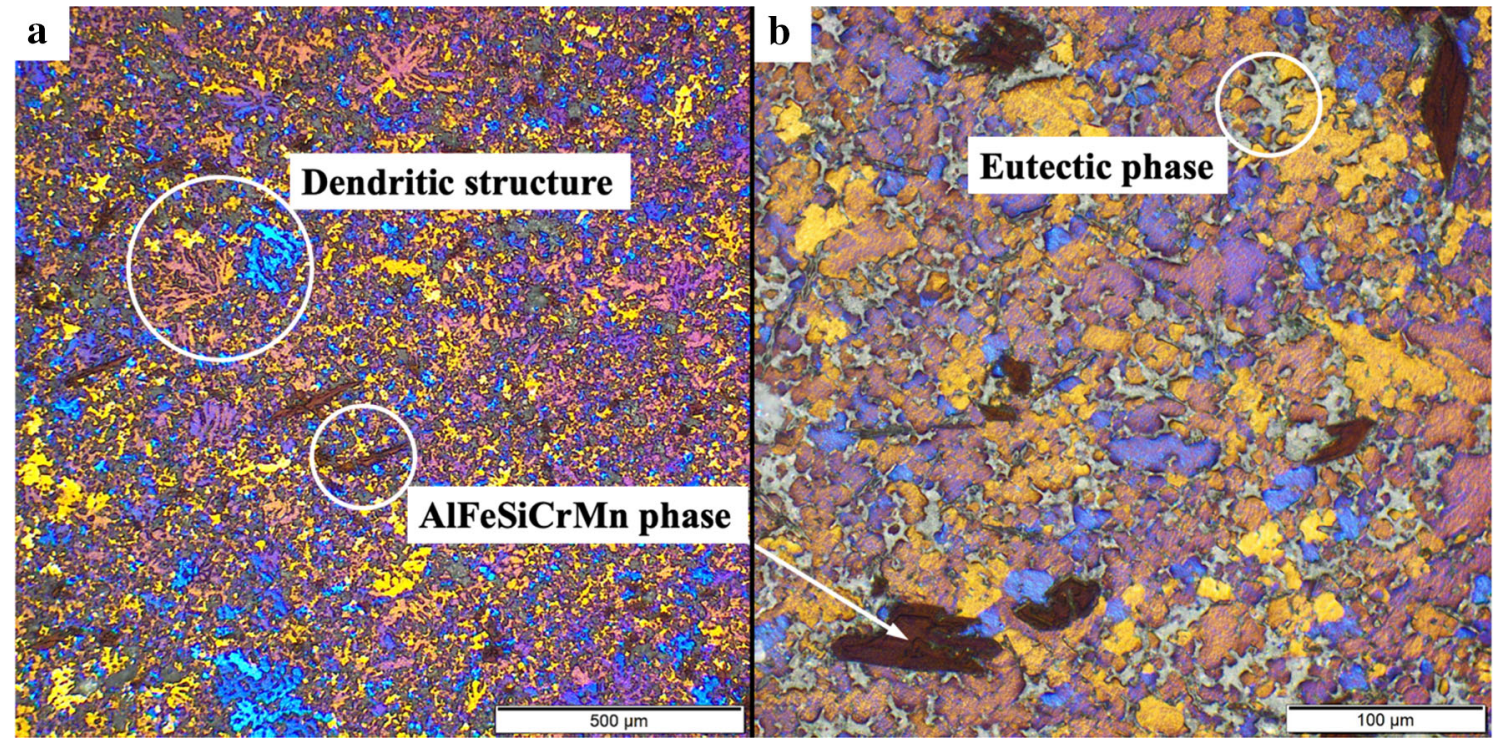

Figure 13. OM: $A I Z n 4 M g 3 C u(F e)$ as cast after Barker etching at (a) low and (b) high magnification. 


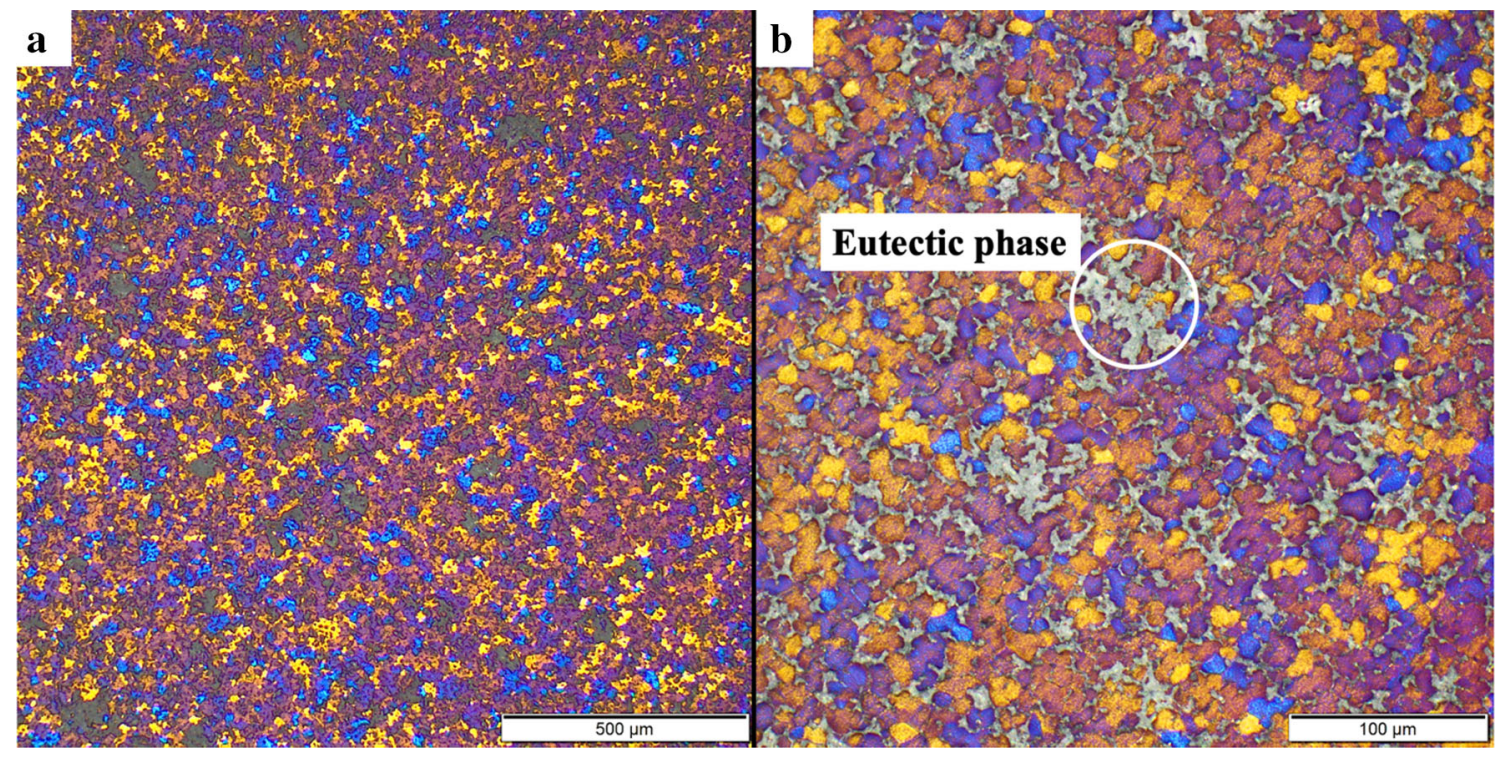

Figure 14. OM: AIZn5Mg4Cu as cast after Barker etching at (a) low and (b) high magnification.

\section{Acknowledgements}

This work was supported by the European Regional Development Fund (ERDF) within the program "IWB Investitionen in Wachstum und Beschäftigung Österreich 2014-2020" and funds from the Province of Upper Austria.

Open Access This article is licensed under a Creative Commons Attribution 4.0 International License, which permits use, sharing, adaptation, distribution and reproduction in any medium or format, as long as you give appropriate credit to the original author(s) and the source, provide a link to the Creative Commons licence, and indicate if changes were made. The images or other third party material in this article are included in the article's Creative Commons licence, unless indicated otherwise in a credit line to the material. If material is not included in the article's Creative Commons licence and your intended use is not permitted by statutory regulation or exceeds the permitted use, you will need to obtain permission directly from the copyright holder. To view a copy of this licence, visit http://creativecommons. org/licenses/by/4.0/.

\section{Funding}

Open access funding provided by University of Applied Sciences Upper Austria.

\section{REFERENCES}

1. E. Hornbogen, R. Bode, P. Donner, Recycling: Materialwissenschaftliche Aspekte (Springer, Berlin, 1993), p. 21

2. F. Ostermann, Anwendungstechnologie Aluminium (Springer, Berlin, 2014), p. 142

3. U. Heubner, Entwicklung einer hochfesten Aluminiumlegierung vom Typ AlZnMg, welche gut schweißbar und unempfindlich gegen Spannungsrißkorrosion ist, Zentralstelle für Luft- und
Raumfahrtdokumentation und -information der Dt. Forschungs- und Versuchsanstalt für Luft- und Raumfahrt, Munich (1976)

4. N.J.H. Holroyd, G.M. Scamans, Metall. Mater. Trans. A 44, 1230 (2013)

5. F. Stein, M. Palm, G. Sauthoff, Intermetallics 12, 713 (2004)

6. Y. Komura, M. Mitarai, I. Nakatani, H. Iba, T. Shimizu, Acta Crystallogr. Sect. B: Struct. Crystallogr. Cryst. Chem. 26, 666 (1970)

7. M.J. Styles, T.J. Bastow, M.A. Gibson, C.R. Hutchinson, Intermetallics 49, 40 (2014)

8. V.V. Zakharov, T.D. Rostova, I.A. Fisenko, Met. Sci. Heat Treat. 47, 377 (2005)

9. L.F. Mondolfo, Aluminum Alloys: Structure and Properties, vol. 842 (Butterworth-Heinemann, London, 1976)

10. C. Mondal, A.K. Mukhopadhyay, Mater. Sci. Eng. A 391, 367 (2005)

11. T. Sheppard, Extrusion of Aluminium Alloys, vol. 227 (Kluwer, London, 1999)

12. J. Vetterlein, Charakterisierung von Wärmebehandlungszuständen in Aluminiumlegierungen durch Insitu-Wirbelstrommessung, Ph.D. Thesis, University Bremen, Aachen (2008)

13. T. Pabel, S. Bozorgi, C. Kneiß1, K. Haberl, P. Schumacher, Berg-Huettenmaenn. Monthsh. 156, 261 (2011)

14. S. Staggl, S. Bozorgi, T. Pabel, K. Faerber, C. Kneißl, P. Schumacher, Gießerei-Runds. 59, 138 (2012)

15. E. Scheil, Z. Metallkd. 34, 70 (1942)

16. G.H. Gulliver, J. Inst. Met. 9, 120 (1913)

17. European Committee for Standardization (CEN), DIN EN 1706:2013-12, Aluminium und Aluminiumlegierungen-Gussstücke-Chemische Zusammensetzung und mechanische Eigenschaften, Brussels, 17 (2013) 
18. A. Zyska, Z. Konopka, M. Łągiewka, M. Nadolski, Arch. Foundry Eng. 8, 123 (2008)

19. Z. Hennadiy, Optimierung von höchstfesten $\mathrm{AlZnMgCu}$-Legierungen für den Kokillenguss, Ph.D. Thesis, Clausthal University of Technology (2017)

20. J. Liu, M. Kulak, Mater. Sci. Forum 331-337, 127 (2000)

21. A. Kelly, R.B. Nicholson, Prog. Mater. Sci. 10, 216 (1963)

22. M.H. Jacobs, TALAT Lect. 1204, 18 (1999)

23. M.F. Ibrahim, G.H. Garza-Elizondo, A.M. Samuel, F.H. Samuel, Int. J. Metalcast. 10, 264-275 (2016). https://doi.org/10.1007/s40962-016-0038-2

24. F. Ostermann, Air Force Materials Laboratory, unpublished results (1970)

25. S. Klan, Beitrag zur Evolution von AluminiumGusslegierungen für warmfeste Anwendungen, Ph.D. Thesis, Freiberg University of Technology (2004)

26. M.N. Binney, D.H. St John, A.K. Dahle, Light metals 2003: proceedings of the technical sessions presented by the TMS Aluminium Committee at the 132nd TMS annual meeting, San Diego, California, March 2-6, 917 (2003)

27. S. Ji, W. Yang, F. Gao, D. Watson, Z. Fan, Mater. Sci. Eng. A 564, 130 (2013)

28. M. Sacinti, E. Cubuklusu, Y. Birol, Int. J. Cast Met. Res. 30, 96 (2017)

29. O. Vorren, J.E. Evensen, T.B. Pedersen, AFS Trans. 92, 459 (1984)
30. M.D. David, R.D. Foley, J.A. Griffin, C.A. Monroe, Int. J. Metalcast. 10, 2 (2016). https://doi.org/10.1007/ s40962-015-0006-2

31. N. Birbilis, M.K. Cavanaugh, R.G. Buchheit, Corros. Sci. 48, 4202 (2006)

32. J.P. Wloka, Korrosionsuntersuchungen an scandiumhaltigen $\mathrm{AlZnMgCu}$-Legierungen unter besonderer Berücksichtigung des Einflusses intermetallischer Phasen, Ph.D. thesis, University of Erlangen-Nuremberg (2007)

33. G. Gottstein, Materialwissenschaft und Werkstofftechnik: Physikalische Grundlagen, 4th edn. (Springer Vieweg, Berlin, 2014), p. 265

34. E. Ghassemali, M. Riestra, T. Bogdanoff, B.S. Kumar, S. Seifeddine, Procedia Eng. 207, 19 (2017)

35. Y. Birol, Mater. Sci. Eng. A 559, 394 (2013)

36. E. Samuel, B. Golbahar, A.M. Samuel, H.W. Doty, S. Valtierra, F.H. Samuel, Mater. Des. 56, 468 (2014)

37. S.A. Kori, B.S. Murty, M. Chakraborty, Mater. Sci. Eng. A 283, 94 (2000)

38. K.G. Basavakumar, P.G. Mukunda, M. Chakraborty, Mater. Charact. 59, 283 (2008)

39. S. Li, Hot Tearing in Cast Aluminum Alloys: Measures and Effects of Process Variables, Ph.D. Thesis, Worcester Polytechnic Institute (2010)

40. D.G. McCartney, Int. Mater. Rev. 34, 247 (1989)

Publisher's Note Springer Nature remains neutral with regard to jurisdictional claims in published maps and institutional affiliations. 